\title{
Unusual Detection of Lathosterol in Amniotic Fluids Investigated for the Determination of Cholesterol and 7-Dehydrocholesterol for Suspected Smith-Lemli-Opitz Syndrome
}

\author{
Veniero Gambaro', Fiorenza Farè ${ }^{1}$, Andrea Barlocco², Federico Maggi², Giuseppe Simoni², \\ Lucia Dell'Acqua ${ }^{1}$, Chiara Rusconi' ${ }^{1}$, Gabriella Roda ${ }^{*}$ \\ ${ }^{1}$ Dipartimento di Scienze Farmaceutiche "Pietro Pratesi", University of Milan, Milan, Italy \\ ${ }^{2}$ Laboratorio TOMA srl, Busto Arsizio, Italy \\ Email: "gabriella.roda@unimi.it
}

Received 28 January 2014; revised 2 March 2014; accepted 10 March 2014

Copyright (C) 2014 by authors and Scientific Research Publishing Inc.

This work is licensed under the Creative Commons Attribution International License (CC BY).

http://creativecommons.org/licenses/by/4.0/

$$
\text { (c) (i) Dpen Access }
$$

\begin{abstract}
The Smith-Lemli-Opitz syndrome (SLOS), is an autosomal recessive disorder caused by a 7-dehydrocholesterol reductase deficiency, which is characterized by abnormally elevated amniotic fluid 7-DHC (7-dehydrocholesterol) concentrations. A GC/FID (gas-chromatography with a flame ionization detector) and GC/MS (gas-chromatography with a mass detector) method was optimized for the detection of cholesterol and 7-DHC in amniotic fluids. The quantitative determination of cholesterol in 39 control amniotic fluids evidenced that between the fourth and fifth month of pregnancy the levels of this analyte are quite constant, the concentration of total and free cholesterol being respectively $10.3 \mu \mathrm{g} \cdot \mathrm{mL}^{-1}(S D= \pm 3.6)$ and $1.7 \mu \mathrm{g} \cdot \mathrm{mL}^{-1}(\mathrm{SD}= \pm 0.91)$, while the analysis of 60 amniotic fluids potentially related to SLOS, showed a higher variability of cholesterol levels. Moreover, in 13 samples an analyte which did not correspond either to cholesterol or to 7-DHC was detected. A GC/MS investigation allowed us to identify this compound as lathosterol, a precursor of cholesterol in the biosynthetic pathway.
\end{abstract}

\section{Keywords}

Lathosterol; Cholesterol; SLO Syndrome; Amniotic Fluid; GC/FID; GC/MS

\footnotetext{
${ }^{*}$ Corresponding author.
}

How to cite this paper: Gambaro, V., et al. (2014) Unusual Detection of Lathosterol in Amniotic Fluids Investigated for the Determination of Cholesterol and 7-Dehydrocholesterol for Suspected Smith-Lemli-Opitz Syndrome. American Journal of Analytical Chemistry, 5, 249-257. http://dx.doi.org/10.4236/ajac.2014.54031 


\section{Introduction}

Cholesterol is an essential lipid which is a precursor for many sterol-based compounds and is involved in the regulation of the precise pattering of embryonic structures [1]. Thus, a defeat in its availability during pregnancy has severe consequences to the fetus, interfering in its regular development [2].

Cholesterol is produced from lanosterol through a complex biosynthetic pathway involving several multienzymatic reactions, including demethylations, isomerization, desaturation, and double-bond reductions. Several polimalformative disorders [3]-[6] have been identified, deriving from enzyme defects in cholesterol biosynthesis [7] [8]. In particular the Smith-Lemli-Opitz syndrome (SLOS), is an autosomal recessive disorder affecting 1:20000 individuals, characterized by a recognizable pattern of minor facial anomalies, limb abnormalities and multiple congenital anomalies including pseudohermaphroditism in males, neonatal hypotonia, mental retardation and failure to thrive [9]-[12]. This disease, caused by a 7-dehydrocholesterol reductase deficiency, is characterized by high blood levels of specific metabolites of postsqualene cholesterol biosynthesis [13]. A clinical suspicion of SLOS is usually confirmed by a marked increase of 7-dehydrocholesterol (7-DHC) in plasma or tissues, accompanied by decreased levels of cholesterol, which is consistent with a 7-dehydrocholesterol reductase deficiency [14]. The determination of serum cholesterol and 7-DHC by GC/MS is the method of choice for SLOS diagnosis [15], even if other analytical approaches have been described [16]-[18] Figure 1. This method was also applied to the prenatal diagnosis for the determination of sterols in amniotic fluid [15] [19]-[26]. It was demonstrated that abnormally elevated amniotic fluid 7-DHC concentrations are an accurate predictor of fetal SLOS [27] [28]. In this paper, we describe the results obtained for the determination of free cholesterol, total cholesterol and its derivatives in 39 amniotic fluids without genetic alterations, considered as control fluids and in 60 amniotic fluids withdrawn from pregnant women, showing a fetal growth retardation potentially related to SLOS, in order to confirm the correlation between this pathology and the sterol levels in amniotic fluid.

The fetal growth retardation were divided into three classes: an overt intra uterine growth retardation (IUGR), a smaller fetus respect to the gestational age (SGA) and cases in which further biomedical studies were necessary (ACC).

In the case of the amniotic fluids related to fetal growth retardations only the quantitative determination of total cholesterol was carried out, in fact it was not possible to determine its free portion because of the small amount of amniotic fluid available after the routine cytogenetic investigations.

In the screening phase the determinations were carried out by means of the GC/FID technique, which allows a fast and accurate quali-quantitative detection of the analytes of interest; the fluids which presented altered concentration values of sterols were further investigated by GC/MS, a technique able to detect compounds structurally related to cholesterol, belonging to its biosynthetic pathway.

\section{Experimental}

\subsection{Materials}

All reagents and solvents were of analytical-reagent grade. Cholesterol, 7-DHC, lathosterol and stigmasterol were purchased from Sigma (St. Louis, MO), cyclohexane was obtained from J.T. Baker (Phillipsburg, NJ), ethanol from Carlo Erba (Milano), $\mathrm{KOH}$ and pyridine from Merck (Darmstadt), $0.9 \% \mathrm{NaCl}$ solution from Baxter (Trieste).

Derivatization reagents were N,O-bis(trimethylsilyl)trifluoroacetamide (BSTFA) with 1\% trimethylchlorosilano (TMCS) (Supelco inc., Bellafonte).

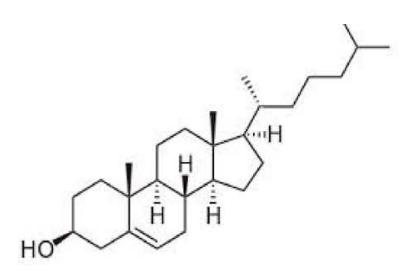

cholesterol

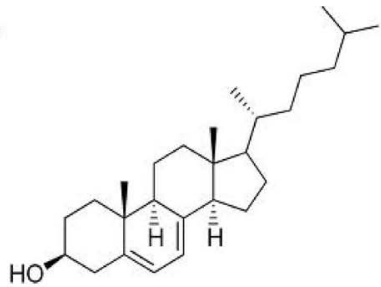

7-dehydrocholesterol

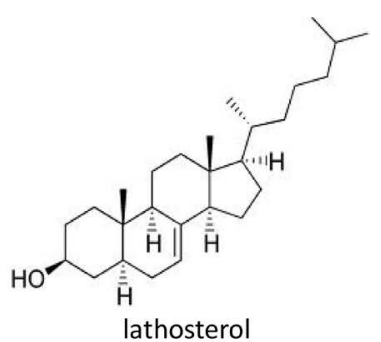

lathosterol

Figure 1. Chemical structure of cholesterol, 7-dehydrocholesterol, lathosterol. 
Statistic analysis was carried out by means of ANOVA test, following the ICH rules.

\section{Standard Solutions}

Stock standard solutions $\left(1 \mathrm{mg} \cdot \mathrm{mL}^{-1}\right.$ ) of cholesterol, 7-DHC and stigmasterol (internal standard, IS) were prepared in cyclohexane and then diluted in volumetric flasks to concentrations of 50.0, 100.0, 150.0, 200.0, 300.0, 400.0, 600.0, $800.0 \mu \mathrm{g} \cdot \mathrm{mL}^{-1}$ for cholesterol; 2.0, 5.0, 7.0, 10.0, 15.0, 20.0, 30.0, $50.0 \mu \mathrm{g} \cdot \mathrm{mL}^{-1}$ for 7-DHC and $50.0 \mu \mathrm{g} \cdot \mathrm{mL}^{-1}$ for IS and stored at $4^{\circ} \mathrm{C}$ for up to a month.

\subsection{Standard Samples Preparation}

Aliquots of $0.1 \mathrm{~mL}$ of standard solution of cholesterol and 7-DHC, were placed in a $10 \mathrm{~mL}$ conical tube and cycloexane was evaporated. $1.0 \mathrm{~mL}$ of physiologic solution $(\mathrm{NaCl} 0.9 \%)$ and $0.1 \mathrm{~mL}$ of the internal standard solution $\left(50.0 \mu \mathrm{g} \mathrm{mL}^{-1}\right)$ were added to the residue. The standard samples underwent the extraction procedure as described in paragraph 2.5 .

\subsection{Amniotic Fluids (AF)}

$39 \mathrm{AF}$, taken by amniocentesis from women with a normal fetal growth between the $14^{\text {th }}$ and the $21^{\text {st }}$ week of pregnancy, were supplied by Laboratorio TOMA; $60 \mathrm{AF}$, taken by women between the $23^{\text {th }}$ and the $37^{\text {th }}$ week of pregnancy showing a retardation in the fetal growth potentially related to SLOS, were obtained from Policlinico Nuovo S. Eugenio (University "Tor Vergata" of Rome). The amniotic fluids were stored at $+4^{\circ} \mathrm{C}$ until analysis.

Amniotic fluids were withdrawn on the patient's request to carry out prenatal cytogenetic analysis under current Italian law. After cytogenetic analysis on the supernatant the determination of cholesterol and 7-DHC was performed.

\subsection{Extraction}

The total amount of cholesterol and 7-DHC were obtained from amniotic fluids by the liquid-liquid extraction protocol reported below. $0.5 \mathrm{~mL}$ of amniotic fluid samples added with $0.5 \mathrm{~mL}$ of physiologic solution were placed in a $10 \mathrm{~mL}$ glass tube; the mixture was spiked with $0.1 \mathrm{~mL}$ of IS $\left(50.0 \mu \mathrm{g} \mathrm{mL}{ }^{-1}\right)$, saponified for $60 \mathrm{~min}$ at $60^{\circ} \mathrm{C}$ with $1 \mathrm{~mL} 1 \mathrm{M} \mathrm{KOH}$ in $90 \%$ ethanol and extracted three times with $1 \mathrm{~mL}$ cycloexane. The tubes were centrifuged at $7000 \mathrm{rpm}$ for $10 \mathrm{~min}$ and the organic phase was isolated. After evaporation of the solvent, the residue was derivatized with $100 \mu \mathrm{L}$ BSTFA + TMCS in pyridine (1:1) at $60^{\circ} \mathrm{C}$ for $1 \mathrm{~h}$. The derivatized samples were analysed by capillary gas chromatography with a flame ionization detector (CGC/FID) and peak identity was confirmed by capillary gas chromatography coupled with a mass spectrometry (CGC/MS).

Free cholesterol concentrations were obtained following an analogous protocol, omitting the saponification procedure.

\subsection{GC/FID Analysis}

Aliquots $(2 \mu \mathrm{L})$ of the derivatized samples were injected (model 7673 autosampler, Hewlett Packard, Palo Alto, CA) into a CGC/FID system consisting in a Hewlett Packard GC (model 5890 series II) equipped with a flame ionization detector (FID) and controlled with a Chemstation software. Chromatographic conditions were as follows: a fused-silica capillary Hewlett Packard column (HP-1, $12 \mathrm{~m} \times 0.20 \mathrm{~mm}$ i.d., stationary phase, $0.33 \mu \mathrm{m}$ methyl silicone) was used for separation with helium as the carrier gas (flow rate: $1 \mathrm{~mL} \mathrm{~min}^{-1}$ ). The injector and detector temperatures were $280^{\circ} \mathrm{C}$ and $300^{\circ} \mathrm{C}$ respectively and the oven temperature was raised from 200 to $300^{\circ} \mathrm{C}$ at $8^{\circ} \mathrm{C} / \mathrm{min}$ and held constant for $2.5 \mathrm{~min}$. The total analysis time was $15 \mathrm{~min} .1 \mu \mathrm{L}$ of sample was injected in a spitless mode TMS derivatives of cholesterol and 7-DHC in amniotic fluid samples were identified by comparing their retention time with those of the TMS derivatives of the authentic compounds (Sigma).

\subsection{GC/MS Analysis}

The qualitative analyses were performed using an a Hewlett Packard (Palo Alto, CA) model 5890 series II instrument equipped with a 7673A automatic injector with electronic pressure control and interfaced to a HP 5971A mass selective detector. HP Chemstation software was used for data acquisition and processing. GC op- 
erating conditions were as follows: a fused-silica capillary column HP-5 MS (30 m $\times 0.25-\mathrm{mm}$ i.d., $0.25-\mu \mathrm{m}$ film thickness) was used with helium as the carrier gas (flow rate: $1 \mathrm{~mL} \mathrm{~min}^{-1}$ ). The injector and detector temperatures were $280^{\circ} \mathrm{C}$ and $300^{\circ} \mathrm{C}$ respectively; the oven temperature was raised from $70^{\circ} \mathrm{C}$ to $220^{\circ} \mathrm{C}$ at $40^{\circ} \mathrm{C} / \mathrm{min}$ and then to $320^{\circ} \mathrm{C}$ at $10^{\circ} \mathrm{C} / \mathrm{min}$ and held constant for $2 \mathrm{~min}$. The total analysis time was $15 \mathrm{~min} .1 \mu \mathrm{L}$ of sample was injected in a spitless mode. MS was operated in EI mode at $70 \mathrm{eV}$. For MS mode, full scan spectral acquisition was run at 1 scan per second and begun at $\mathrm{m} / \mathrm{z} 40$ to $\mathrm{m} / \mathrm{z} 550$. TMS derivatives of cholesterol and 7-DHC in amniotic fluid samples were identified by comparing their retention time and mass spectra with those of the TMS derivatives of authentic compounds (Sigma).

\section{Validation}

\subsection{Linearity}

Five standard samples at different concentration levels ranging from 5.0 to $80.0 \mu \mathrm{g} \mathrm{mL} \mathrm{m}^{-1}$ for cholesterol and from 0.2 to $5.0 \mu \mathrm{g} \mathrm{mL}^{-1}$ for 7-DHC were prepared and checked for linearity. For every solution at different concentration five different samples were prepared. The calibration curves were obtained plotting the response ratio (area of the analyte/area of the IS) versus the concentration using the least-squares method. The statistic pararemeters are reported in Table 1.

\subsection{Precision}

Precision, the degree of agreement among individual test results when the procedure is applied repeatedly to multiple samplings, expressed as coefficient of variation (\%CV), was evaluated by replicate analyses of samples with concentration 15.0, 30.0, $60.0 \mu \mathrm{g} \mathrm{mL}^{-1}$ for cholesterol and $0.7,1.5,3.0 \mu \mathrm{g} \mathrm{mL} \mathrm{L}^{-1}$ for 7-DHC. For the intra-day precision the analyses were carried out in one laboratory by one operator, using the same reagents and instruments over a relatively short time span. Results are shown in Table 2. Inter-day precision was assessed performing two sets of six analyses carried out over different days, verifying that the coefficients of variation of each set were not significantly different (ANOVA test). Results are shown in Table 3.

\subsection{Accuracy/Recovery}

The accuracy of the method is defined as the degree of the agreement of test result generated by the method to the true value. Accuracy of the method was checked at three concentration levels: $15.0,30.0,60.0 \mathrm{mg} \mathrm{mL}^{-1}$ for cholesterol and $0.7,1.5,3.0 \mathrm{mg} \mathrm{mL}^{-1}$ for 7-DHC. The analytical recovery was used to assess the accuracy and the accuracy was determined by evaluating standard samples containing known amounts of cholesterol and 7-DHC respectively, and using calibration curves to predict concentration value. Results are shown in Table 4.

\subsection{Limits of Detection (LOD) and of Quantitation (LOQ)}

The LOD, defined as the lowest concentration of analyte that can be clearly detected, is estimated as three times the signal to noise ratio. The LOD was determined by injecting standard solution of various concentrations. For this method, the minimum concentration of cholesterol and 7-DHC that could be detected was $0.02 \mu \mathrm{g} \mathrm{mL}^{-1}$. The LOQ of cholesterol and 7-DHC, (signal to noise ratio of 10/1) was 0.5 and $0.2 \mu \mathrm{g} \mathrm{mL}^{-1}$, respectively.

\subsection{Stability of Cholesterol in Amniotic Fluids}

Stability of cholesterol in amniotic fluids was evaluated in three different samples taken from women with the same age and pregnancy week. The sample were divided into two portions and conserved at $4^{\circ} \mathrm{C}$ and $20^{\circ} \mathrm{C}$. The total concentration of cholesterol after one, two, seven and fifteen days was determined in each sample as described above (Table 5). In the same way in Table 6 the results obtained for the stability of derivatized cholesterol are reported.

\section{Results and Discussion}

The data obtained in the validation procedure demonstrate that the analytical method is suitable for the quali-quantitative determination of cholesterol and 7-DHC in amniotic fluids. In particular the method resulted to be easy to apply, linear, accurate, reproducible, repeatable, sensitive and selective (there were no interfering 
Table 1. Linearity results of cholesterol and 7-DHC.

\begin{tabular}{|c|c|c|}
\hline Compound & Results & Value from $t$-test significance table $(\alpha=0.05)$ \\
\hline \multicolumn{3}{|l|}{ Cholesterol } \\
\hline Linear range $\left(\mu \mathrm{g} \cdot \mathrm{mL}^{-1}\right)$ & $5.0-80.0$ & \\
\hline $\mathrm{n}$ & 25 & \\
\hline Slope $(b)$ & 0.106 & \\
\hline Intercept $(a)$ & -0.016 & \\
\hline Correlation coefficient (r) & 0.9997 & \\
\hline $\mathrm{CV} \%$ & 2.3 & \\
\hline Confidence limits of $a$ & \pm 0.234 & \\
\hline t-student & -0.14 & 2.07 \\
\hline \multicolumn{3}{|l|}{ ANOVA test: } \\
\hline F-test (Regression) & 34426 & 4.35 \\
\hline F-test (Deviation from linearity) & 1.677 & 3.10 \\
\hline \multicolumn{3}{|l|}{ 7-DHC } \\
\hline Linear range $\left(\mu \mathrm{g} \cdot \mathrm{mL}^{-1}\right)$ & $0.2-5.0$ & \\
\hline $\mathrm{n}$ & 25 & \\
\hline Slope (b) & 0.081 & \\
\hline Intercept $(a)$ & 0.021 & \\
\hline Correlation coefficient (r) & 0.9988 & \\
\hline $\mathrm{CV} \%$ & 5.1 & \\
\hline Confidence limits of $a$ & \pm 0.020 & \\
\hline t-student & 2.04 & 2.07 \\
\hline \multicolumn{3}{|l|}{ ANOVA test: } \\
\hline F-test (Regression) & 9469 & 4.35 \\
\hline F-test (Deviation from linearity) & 5.575 & 3.10 \\
\hline
\end{tabular}

Table 2. Intra-day precision of cholesterol and 7-DHC.

\begin{tabular}{|c|c|c|c|c|c|}
\hline \multicolumn{3}{|l|}{ Cholesterol } & \multicolumn{2}{|l|}{ 7-DHC } & \multirow[b]{2}{*}{$\mathrm{CV} \%$} \\
\hline $\begin{array}{c}\text { Added } \\
\left(\mu \mathrm{g} \cdot \mathrm{mL}^{-1}\right)\end{array}$ & $\begin{array}{c}\text { Measured } \\
\text { (mean } \pm \text { SD) } \\
n=6\end{array}$ & $\mathrm{CV} \%$ & $\begin{array}{c}\text { Added } \\
\left(\mu \mathrm{g} \cdot \mathrm{mL}^{-1}\right)\end{array}$ & $\begin{array}{c}\text { Measured } \\
\text { (mean } \pm \text { SD) } \\
n=6\end{array}$ & \\
\hline 15.0 & $15.5 \pm 0.2$ & 1.5 & 0.7 & $0.5 \pm 0.02$ & 3.8 \\
\hline 30.0 & $30.9 \pm 0.5$ & 1.6 & 1.5 & $0.9 \pm 0.06$ & 6.7 \\
\hline 60.0 & $60.6 \pm 1.0$ & 1.6 & 3.0 & $2.5 \pm 0.08$ & 3.5 \\
\hline
\end{tabular}

Table 3. Inter-day precision of cholesterol and 7-DHC.

\begin{tabular}{|c|c|c|c|c|c|c|c|}
\hline \multirow{2}{*}{$\begin{array}{c}\text { Cholesterol } \\
\text { Added } \\
\left(\mu \mathrm{g} \cdot \mathrm{mL}^{-1}\right)\end{array}$} & \multicolumn{7}{|c|}{ 7-DHC } \\
\hline & $\begin{array}{c}\text { Measured } \\
\text { (mean } \pm \text { SD) } \\
n=6+6\end{array}$ & $\mathrm{CV} \%$ & F-test ${ }^{\mathrm{a}}$ & $\begin{array}{c}\text { Added } \\
\left(\mu \mathrm{g} \cdot \mathrm{mL}^{-1}\right)\end{array}$ & $\begin{array}{c}\text { Measured } \\
\text { (mean } \pm \text { SD) } \\
n=6+6\end{array}$ & $\mathrm{CV} \%$ & F-test ${ }^{\mathrm{a}}$ \\
\hline 15.0 & $15.2 \pm 0.2$ & 1.3 & 3.773 & 0.7 & $0.4 \pm 0.03$ & 7.4 & 3.922 \\
\hline 30.0 & $30.8 \pm 0.5$ & 1.8 & 0.045 & 1.5 & $0.9 \pm 0.02$ & 2.6 & 3.879 \\
\hline 60.0 & $61.7 \pm 0.6$ & 1.0 & 4.041 & 3.0 & $2.5 \pm 0.06$ & 2.5 & 3.922 \\
\hline
\end{tabular}

${ }^{\mathrm{a}}$ Value from table 4.960, $\alpha=0.05$. 
Table 4. Recovery of cholesterol and 7-DHC.

\begin{tabular}{cccccc}
\hline $\begin{array}{c}\text { Cholesterol } \\
\begin{array}{c}\text { Concentration } \\
\left(\mu \mathrm{g} \cdot \mathrm{mL}^{-1}\right)\end{array}\end{array}$ & $\begin{array}{c}\text { Recovery }(\%) \pm \mathrm{SD} \\
(\mathrm{n}=6)\end{array}$ & $\mathrm{CV} \%$ & $\begin{array}{c}\text { 7-DHC } \\
\left(\mu \mathrm{g} \cdot \mathrm{mL}^{-1}\right)\end{array}$ & $\begin{array}{c}\text { Recovery }(\%) \pm \mathrm{SD} \\
(\mathrm{n}=6)\end{array}$ & $\mathrm{CV} \%$ \\
\hline 15.0 & $95.9 \pm 1.8$ & 1.8 & 0.7 & $65.1 \pm 3.6$ & 5.5 \\
30.0 & $93.8 \pm 3.1$ & 3.3 & 1.5 & $73.6 \pm 2.1$ & 2.8 \\
60.0 & $94.2 \pm 2.6$ & 2.7 & 3.0 & $79.7 \pm 2.5$ & 3.1 \\
\hline
\end{tabular}

Table 5. Stability of total cholesterol in amniotic fluids at $+4^{\circ} \mathrm{C}$ and $+20^{\circ} \mathrm{C}$.

\begin{tabular}{ccccc}
\hline & & & $+20^{\circ} \mathrm{C}$ \\
Sample & mean $^{\mathrm{a}} \pm \mathrm{SD}(\mathrm{n}=4)$ & $\mathrm{CV} \%$ & mean $^{\mathrm{a}} \pm \mathrm{SD}(\mathrm{n}=4)$ & $\mathrm{CV} \%$ \\
\hline 1 & $12.3 \pm 0.3$ & 2.5 & $12.3 \pm 1.1$ & 8.6 \\
2 & $8.7 \pm 0.5$ & 5.6 & $8.8 \pm 0.5$ & 5.6 \\
3 & $10.9 \pm 1.2$ & 11.2 & $10.1 \pm 0.6$ & 6.2 \\
\hline
\end{tabular}

${ }^{\mathrm{a}} \mu \mathrm{g} \cdot \mathrm{mL}^{-1}$.

Table 6. Stability of total cholesterol derivatized at $+4^{\circ} \mathrm{C}$ and $+20^{\circ} \mathrm{C}$.

\begin{tabular}{ccccc}
\hline & & & $+20^{\circ} \mathrm{C}$ & \\
\hline Sample & mean $^{\mathrm{a}} \pm \mathrm{SD}(\mathrm{n}=4)$ & $\mathrm{CV} \%$ & mean $^{\mathrm{a}} \pm \mathrm{SD}(\mathrm{n}=4)$ & 1.1 \\
\hline 1 & $12.5 \pm 0.2$ & 1.8 & $13.3 \pm 0.1$ & 1.4 \\
2 & $8.9 \pm 0.3$ & 3.1 & $8.7 \pm 0.1$ & 1.1 \\
3 & $11.3 \pm 0.1$ & 1.3 & $11.1 \pm 0.1$ & $\mathrm{CV} \%$ \\
\hline
\end{tabular}

${ }^{\mathrm{a}} \mu \mathrm{g} \cdot \mathrm{mL}^{-1}$.

species in the range of analysis of interest), even if a significant background noise was evidenced due to the pyridine employed in the derivatization protocol.

Another important point assessed was the stability of the analytes either at $4{ }^{\circ} \mathrm{C}$ or at $20^{\circ} \mathrm{C}$, which is crucial because frequently it is not possible to analyse the amniotic fluids immediately after the withdrawal. In fact in many cases the fluids related to fetal growth retardations undergo preliminary genetic investigations.

\subsection{Control Amniotic Fluids}

39 amniotic fluids taken between the $14^{\text {th }}$ and the $21^{\text {th }}$ week of pregnancy from women whose age ranged from 27 to 40 years were analysed. The cytogenetic analysis carried out on the amniocytes did not evidence any cytogenetic abnormalities, so these fluids were considered as control fluids. In these samples either the total concentration of cholesterol or the concentration of its free portion were determined (Table 7). It can be noted that there is not a significant variation in the concentration of cholesterol depending on the week of pregnancy, even if a lot of factors such as the age of the woman, the alimentary behaviour and the total volume of amniotic fluid could affect the level of this analyte. A particularly high value of total cholesterol was noticed in the sample taken at the $21^{\text {th }}$ week, while at the $14^{\text {th }}$ week this value was quite low. The determination of the free and total cholesterol in the control fluids evidenced a relatively constant value in particularly between the forth and the fifth month of pregnancy, the mean value of total and free cholesterol being respectively $10.3 \mu \mathrm{gL}^{-1}(\mathrm{SD} \pm 3.6)$ and $1.7 \mu \mathrm{g} \mathrm{mL} \mathrm{m}^{-1}(\mathrm{SD} \pm 0.91)$.

\subsection{Amniotic Fluids Related to Fetal Growth Retardation}

60 amniotic fluids taken from women showing a fetal growth retardation established by means of an echography evaluation were analyzed. The fetal growth retardation were divided into three classes: an overt intra uterine growth retardation (IUGR), a smaller fetus respect to the gestational age (SGA) and cases in which further biomedical studies were necessary (ACC).

The quantitative determination of total cholesterol (it was not possible to determine its free portion because of the small amount of amniotic fluid available) was carried out by means of the GC/FID technique and the results 
obtained are listed in Table 8.

As it is evident, in the cases defined as IUGR, the mean concentration of cholesterol was significantly higher respect to the other cases. This phenomenon is probably related to the fact that in three samples the concentration of total cholesterol was superior to $100 \mu \mathrm{g} / \mathrm{mL}$. These amniotic fluids were taken between the $24^{\text {th }}$ and the $25^{\text {th }}$ week of pregnancy and it we could not establish if this high concentration was related to the gestational age or to other causes, because it was not possible to analyze control fluids of the same gestational age. The variability of the total cholesterol concentration in the fluids in which a fetal growth retardation was established, was however higher than in the control fluids.

Examining the GC chromatograms of the fluids related to a fetal growth retardation, in some of them a peak with a relative retention time (retention time of the analyte/retention time of the IS) of 0.95 was detected which corresponded neither to cholesterol (relative retention time 0.91) nor to 7-DHC (relative retention time 0.94). These samples were therefore investigated by means of the GC/MS technique, which allowed the identification of this peak as lathosterol [14], which is the precursor of 7-DHC in the biosynthesis of cholesterol. The identity of these compound was also confirmed comparing its chromatographic features and MS spectrum with those of a standard of lathosterol. The presence of this sterol was determined in 13 amniotic fluids related to a fetal growth retardation (Table 8).

\section{Conclusion}

A fast, reliable, sensitive and accurate GC/FID method was developed and validated for the determination of cholesterol and 7-DHC in amniotic fluids of women showing a fetal growth retardation potentially related to SLOS. The quantitative determination of cholesterol in control amniotic fluids evidenced that between the fourth and fifth month of pregnancy the levels of this analyte are quite constant, the concentration of total and free

Table 7. Concentration of free and total cholesterol in the control amniotic fluids.

\begin{tabular}{ccccccc}
\hline & & & \multicolumn{2}{c}{$\begin{array}{c}\text { Free cholesterol } \\
\left(\mu \mathrm{g} \cdot \mathrm{mL}^{-1}\right)\end{array}$} & \multicolumn{2}{c}{$\begin{array}{c}\text { Total cholesterol } \\
\left(\mu \mathrm{g} \cdot \mathrm{mL}^{-1}\right)\end{array}$} \\
\hline Weeks gestation & $\mathrm{n}$ & Range mother age & Mean \pm SD & Range & Mean \pm SD & Range \\
\hline 14 & 4 & $32-38$ & $1.3 \pm 0.7$ & $0.5-2.1$ & $5.25 \pm 1.1$ & $3.6-6.7$ \\
15 & 5 & $32-37$ & $1.3 \pm 0.1$ & $1.1-1.5$ & $11.4 \pm 2.6$ & $6.9-14.7$ \\
16 & 9 & $29-41$ & $1.7 \pm 1.0$ & $0.7-3.4$ & $9.4 \pm 2.4$ & $4.8-13.8$ \\
17 & 14 & $27-40$ & $1.6 \pm 9.6$ & $1.1-3.3$ & $10.9 \pm 2.9$ & $5.4-19.5$ \\
18 & 2 & 35 & $3.3 \pm 2.0$ & $1.3-5.3$ & $11.7 \pm 4.0$ & $7.7-15.7$ \\
19 & 1 & 34 & 1.5 & 1.5 & 10.3 & 10.3 \\
20 & 3 & $27-34$ & $1.9 \pm 0.5$ & $1.4-2.5$ & $10.2 \pm 1.3$ & $8.3-11.5$ \\
21 & 1 & 31 & 1.8 & 1.8 & 22.8 & 22.8 \\
& & Total & Total & Total & Total & Total \\
& & $27-41$ & $1.7 \pm 0.9$ & $0.5-5.3$ & $10.3 \pm 3.6$ & $3.6-22.8$ \\
\hline
\end{tabular}

Table 8. Concentration of total cholesterol and lathosterol in the amniotic fluids related to a fetal growth retardation.

\begin{tabular}{ccccc}
\hline & & \multicolumn{2}{c}{ Total cholesterol $\left(\mu \mathrm{g} \cdot \mathrm{mL}^{-1}\right)$} \\
\hline Fetal growth retardation & $\mathrm{n}$ & Weeks of pregnancy & Mean \pm SD & Range \\
\hline IUGR & 20 & $23-34$ & $37.8 \pm 47.9$ & $4.9-154.6$ \\
SGA & 20 & $26-37$ & $14.5 \pm 7.2$ & $5.1-65.1$ \\
\hline ACC & 20 & $25-36$ & $13.2 \pm 13.1$ & Lathosterol $\left(\mu \mathrm{g} \cdot \mathrm{mL}^{-1}\right)$ \\
\hline & & & Mean \pm SD & - \\
\hline Fetal growth retardation & $\mathrm{n}$ & Weeks of pregnancy & 0.53 & $0.41-1.07$ \\
\hline IUGR & 1 & 31 & $0.73 \pm 0.250$ & $0.39-2.21$ \\
\hline SGA & 8 & $26-37$ & $0.90 \pm 0.875$ & \\
\hline ACC & 4 & $25-33$ & & \\
\hline
\end{tabular}


cholesterol being respectively $10.3 \mu \mathrm{g} \cdot \mathrm{mL}^{-1}(\mathrm{SD}= \pm 3.6)$ and $1.7 \mu \mathrm{g} \cdot \mathrm{mL}^{-1}(\mathrm{SD}= \pm 0.91)$. In the amniotic fluids related to fetal growth retardations, a higher variability of cholesterol amounts was found. Moreover in 13 samples an analyte which did not correspond neither to cholesterol nor to 7-DHC was detected. A GC/MS investigation allowed us to identify this compound as lathosterol, a precursor of cholesterol in the biosynthetic pathway. Unfortunately, it was not possible to establish a correlation between the levels of cholesterol and the presence of lathosterol with the possible presence of SLOS pathology in the newborns. In the future, the analytical method will be applied in order to investigate this correlation.

\section{Acknowledgements}

The studies were carried out in part in the laboratory TOMA di Busto Arsizio.

\section{References}

[1] Gofflot, F., Hars, G., Illien, F., Chevy, F., Wolf, C., Picard, J.J. and Roux, C. (2003) Molecular Mechanisms Underlying Limb Anomalies Associated with Cholesterol Deficiency during Gestation: Implications of Hedgehog Signalling. Human Molecular Genetics, 12, 1187-1198. http://dx.doi.org/10.1093/hmg/ddg129

[2] Cardoso, M.L., Balreira, A., Martins, E., Nunes, L., Cabral, A., Marques, M., Lima, M., Reis, M., Marques, J.S., Medeira, A., Cordeiro, I., et al. (2005) Molecular Studies in Portuguese Patients with Smith-Lemli-Opitz Syndrome and Report of Three New Mutations in DHCR7. Molecular Genetics and Metabolism, 85, 228-235. http://dx.doi.org/10.1016/j.ymgme.2005.02.009

[3] Kelley, R.I. and Hernan, G.E. (2001) Inborn Errors of Sterol Biosynthesis. Annual Review of Genomics and Human Genetics, 2, 299-341. http://dx.doi.org/10.1146/annurev.genom.2.1.299

[4] Krakowiak, P.A., Wassif, C.A., Kratz, L., Cozma, D., Kovářová, M., Harris, G., Grinberg, A., Yang, Y., Hunter, A.G.W., Tsokos, M., Kelley, R.I. and Porter, F.D. (2003) Lathosterolosis: An Inborn Error of Human and Murine Cholesterol Synthesis Due to Lathosterol 5-Desaturase Deficiency. Human Molecular Genetics, 12, 1631-1641. http://dx.doi.org/10.1093/hmg/ddg172

[5] Chevy, F., Humbert, L. and Wolf, C. (2005) Sterol Profiling of Amniotic Fluid: A Routine Method for the Detection of Distal Cholesterol Synthesis Deficit. Prenatal Diagnosis, 25, 1000-1006. http://dx.doi.org/10.1002/pd.1254

[6] Brunetti-Pierri, N., Corso, G., Rossi, M., Ferrari, P., Balli, F., Rivasi, F., Annunziata, I., Ballabio, A., Dello Russo, A., Andria, G. and Parenti, G. (2002) Lathosterolosis, a Novel Multiple-Malformation/Mental Retardation Syndrome Due to Deficiency of 3-Hydroxysteroid-5-Desaturase. The American Journal of Human Genetics, 71, 952-958. http://dx.doi.org/10.1086/342668

[7] Clayton, P.T. (1998) Disorders of Cholesterol Biosynthesis. Archives of Diseases in Childhood, 78, 185-189. http://dx.doi.org/10.1136/adc.78.2.185

[8] Porter, F.D. (2003) Human Malformation Syndromes Due to Inborn Errors of Cholesterol Synthesis. Current Opinion in Pediatrics, 15, 607-613. http://dx.doi.org/10.1097/00008480-200312000-00011

[9] Irons, M., Elias, E.R., Salen, G., Tint, G.S. and Batta, A. (1993) Defective Cholesterol Biosynthesis in Smith-LemliOpitz Syndrome. Lancet, 341, 1414. http://dx.doi.org/10.1016/0140-6736(93)90983-N

[10] Tint, G.S., Irons, M., Elias, E.R., Batta, A.K., Frieden, R., Chen, T.S. and Salen, G. (1994) Defective Cholesterol Biosynthesis Associated with the Smith-Lemli-Opitz Syndrome. The New England Journal of Medicine, 330, 107-113. http://dx.doi.org/10.1056/NEJM199401133300205

[11] Tint, G.S., Seller, M., Hughes-Benzie, R., Batta, A.K., Shefer, S., Genest, D., Irons, M., Elias, E. and Salen, G. (1995) Markedly Increased Tissue Concentrations of 7-Dehydrocholesterol Combined with Low Levels of Cholesterol Are Characteristic of the Smith-Lemli-Opitz Syndrome. Journal of Lipid Research, 36, 89-95.

[12] Salen, G., Shefer, S., Batta, A.K., Tint, G.S., Xu, G., Honda, A., Irons, M. and Elias, E. (1996) Abnormal Cholesterol Biosynthesis in the Smith-Lemli-Opitz Syndrome. Journal of Lipid Research, 37, 1169-1180.

[13] Griffiths, W.J., Wang, Y., Karu, K., Samuel, E., McDonnel, S., Hornshaw, M. and Shackleton, C. (2008) Potential of Sterol Analysis by Liquid Chromatography-Tandem Mass Spectrometry for the Prenatal Diagnosis of Smith-LemliOpitz Syndrome. Clinical Chemistry, 54, 1317-1324. http://dx.doi.org/10.1373/clinchem.2007.100644

[14] Amaral, C., Gallardo, E., Rodrigues, R., Pinto Leite, R., Quelhas, D., Tomaz, C. and Cardoso, M.L. (2010) Quantitative Analysis of Five Sterols in Amniotic Fluid by GC-MS: Application to the Diagnosis of Cholesterol Biosynthesis Defects. Journal of Chromatography B, 878, 2130-2136. http://dx.doi.org/10.1016/j.jchromb.2010.06.010

[15] Kelley, R.I. (1995) Diagnosis of Smith-Lemli-Opitz Syndrome by Gas Chromatography/Mass Spectrometry of 7-Dehydrocholesterol in Plasma, Amniotic Fluid and Cultured Skin Fibroblasts. Clinical Chimica Acta, 236, 45-58. 
http://dx.doi.org/10.1016/0009-8981(95)06038-4

[16] Zimmerman, P.A., Hercules, D.M. and Naylor, E.W. (1997) Direct Analysis of Filter Paper Blood Specimens for Identification of Smith-Lemli-Opitz Syndrome Using Time-of-Flight Secondary Ion Mass-Spectrometry. American Journal of Medical Genetics, 68, 300-304. http://dx.doi.org/10.1002/(SICI)1096-8628(19970131)68:3<300::AID-AJMG10>3.0.CO;2-X

[17] Seedorf, U., Fobker, M., Voss, R., Meyer, K., Kannenberg, F., Meschede, D., et al. (1995) Smith-Lemli-Opitz Syndrome Diagnosed by Using Time-of-Flight Secondary-Ion Mass Spectrometry. Clinical Chemistry, 41, 548-552.

[18] Johnson, D.W., ten Brink, H.J. and Jackobs, C. (2001) A Rapid Screening Procedure for Cholesteroland Dehydrocholesterol by Electrospray Ionization Tandem Mass Spectrometry. Journal of Lipid Research, 42, 1699-1705.

[19] Rossiter, J.P., Hofman, K.J. and Kelley, R.I. (1995) Prenatal Diagnosis by Quantification of Cholesterol Precursors in Amniotic Fluid. American Journal of Medical Genetics, 56, 272-275. http://dx.doi.org/10.1002/ajmg.1320560307

[20] Abuelo, D.N., Tint, G.S., Kelley, R., Batta, A.K., Shefer, S. and Salen, G. (1995) Prenatal Detection of the Cholesterol Biosynthetic Defect in the Smith-Lemli-Opitz Syndrome by the Analysis of Amniotic Fluid Sterols. American Journal of Medical Genetics, 56, 281-285. http://dx.doi.org/10.1002/ajmg.1320560309

[21] Dallaire, L., Mitchell, G., Giguère, R., Lefebvre, F., Melançon, S.B. and Lambert, M. (1995) Prenatal Diagnosis of Smith-Lemli-Opitz Syndrome Is Possible by Measurement of 7-Dehydrocholesterol in Amniotic Fluid. Prenatal Diagnosis, 15, 855-858. http://dx.doi.org/10.1002/pd.1970150911

[22] Chevy, F., Humbert, L. and Wolf, C. (2005) Sterol Profiling of Amniotic Fluid: A Routine Method for the Detection of Distal Cholesterol Synthesis Deficit. Prenatal Diagnosis, 25, 1000-1006. http://dx.doi.org/10.1002/pd.1254

[23] Linck, L.M., Hayflick, S.J., Lin, D.S., Battaile, K.P., Ginat, T., Burlingame, S., Gibson, K.M., Honda, M., Honda, A., Salen, G., Tint, G.S., Connor, W.E. and Steiner, R.D. (2000) Fetal Demise with Smith-Lemli-Opitz Syndrome Confirmed by Tissue Sterol Analysis and the Absence of Measurable 7-Dehydrocholesterol $\Delta 7$-Reductase Activity in Chorionic Villi. Prenatal Diagnosis, 20, 238-240. http://dx.doi.org/10.1002/(SICI)1097-0223(200003)20:3<238::AID-PD792>3.0.CO;2-W

[24] McGaughran, J.M., Clayton, P.T., Mills, K.A., Rimmer, S., Moore, L. and Donnai, D. (1995) Prenatal Diagnosis of Smith-Lemli-Opitz Syndrome. American Journal of Medical Genetics, 56, 269-271. http://dx.doi.org/10.1002/ajmg.1320560306

[25] Dallaire, L., Mitchell, G., Giguère, R., Lefebvre, F., Melançon, S.B. and Lambert, M. (1995) Prenatal Diagnosis of Smith-Lemli-Opitz Syndrome Is Possible by Measurement of 7-Dehydrocholesterol. Prenatal Diagnosis, 15, 855-858. http://dx.doi.org/10.1002/pd.1970150911

[26] Abuelo, D.N., Tint, G.S., Kelley, R., Batta, A.K., Shefer, S. and Salen, G. (1995) Prenatal Detection of the Cholesterol Biosynthetic Defect in the Smith-Lemli-Opitz Syndrome by the Analysis of Amniotic Fluid Sterols. American Journal of Medical Genetics, 56, 281-285. http://dx.doi.org/10.1002/ajmg.1320560309

[27] Tint, G.S., Abuelo, D., Till, M., Cordier, M.P., Batta, A.K., Shefer, S., Honda, A., Honda, M., Xu, G., Irons, M., Elias, E.R. and Salen, G. (1998) Fetal Smith-Lemli-Opitz Syndrome Can Be Detected Accurately and Reliably by Measuring Amniotic Fluid Dehydrocholesterols. Prenatal Diagnosis, 18, 651-658. http://dx.doi.org/10.1002/(SICI)1097-0223(199807)18:7<651::AID-PD316>3.0.CO;2-V

[28] Sharp, P., Haan, E., Fletcher, J.M., Khong, T.Y. and Carey, W.F. (1997) First-Trimester Diagnosis of Smith-LemliOpitz Syndrome. Prenatal Diagnosis, 17, 355-361.

http://dx.doi.org/10.1002/(SICI)1097-0223(199704)17:4<355::AID-PD78>3.0.CO;2-M 